\title{
GENDER STEREOTYPES IN ORGANIZATIONS
}

\author{
Jiří Čeněk \\ jiricenda@centrum.cz \\ Masaryk University in Brno, Czech Republik
}

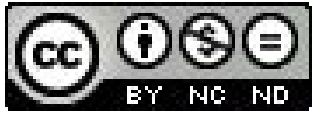

\begin{abstract}
This study is focused on stereotypes of women as managers. The literature review summarizes the most common areas of gender stereotypes. In the empirical part we conducted research on a sample of 111 respondents (students). Research data was obtained by administration of translated and adapted questionnaire Women as Managers Scale (L. Peters et al.). Psychometric analysis of the questionnaire was conducted and its factor structure verified. The goal of this study was to create and pilot Czech adaptation of the questionnaire as an instrument for diagnostics of gender stereotypes in different types of organizations (schools, corporate and public sector).
\end{abstract}

Key words: gender stereotypes, glass ceiling, discrimination

\section{INTRODUCTION}

Although the issue of gender in organizations and management is widely discussed in Western Europe and in USA, in the Czech Republic only the Department of Sociology of Academy of sciences ČR and Research Institute of Labour and Social Affairs conducted more complex research on the problems of gender in organizations.

Gender management and the topic of gender stereotypes can be ranked into areas of diversity management - managing in accordance with interpersonal differences. The central idea of diversity management is that groups of co-workers (teams), achieve better performance, are more flexible and creative, when they consist of workers that differ in their age, social status, gender, race, nationality or experience, compared to homogenous teams (Stockdale, 2004).

The issue of gender in organizations is topical also because of the existence of a phenomenon common in both developed western democracies and post-transformational economies of Middle- and Eastern Europe. This phenomenon is the relatively lower representation of women at the highest levels of corporate hierarchy (top and middle management) compared to that in the general population. According to a study conducted by Vlach (2005) on a research sample of approximately 2850 Czech enterprises the representation of women at I., II. and III. managerial level was at only 41.7 $\%, 27.7 \%$ and $34.9 \%$. In a current rating by the World Economic Forum focussing on equality of men and women in the Czech Republic only 74. out of 134 had comparable status. McKinsey \& Company consultancy firm concluded on the basis of longitudinal researches of the most successful European companies, that the upper quartile of the most successful companies compared to the lower quartile of the least successful always has higher representation of women at the managerial level (Desvaux, 2010). 
Vlach (2008) summarizes studies related to barriers of higher representation of women in management. Apart from factors such as absence of certain competencies which are vital for managers, structural barriers in organizations, informal networks, also the existence of cognitive schemas - stereotypes is incorporated. The basis of gender stereotypes in management is that women are for various reasons less capable of successful performance of managerial roles.

The goal of this empirical study was to explore to what extent Czech students give in to the gender stereotypes in management. The other goal was to create a scale that can be used for diagnostics of gender stereotypes in the Czech environment.

\section{THEORETICAL BACKGROUND}

In this part we will discuss the most common gender stereotypes in organizations. These stereotypes may, and usually do, influence career development of men and women. Very interesting study concerning gender stereotypes is research of Coltrane and Adams (1997). The authors were studying the reflection of gender stereotypes in media and they focused on TV commercials. Authors analyzed 1699 TV commercials and one of their findings was that women are disproportionately associated with family-related roles. Men and women also differ in their depiction in work conditions. Most common depictions of women were women working in administrative occupations and in services, while men were mostly depicted as craftsmen, workmen, businessman and managers. Men were compared to women relatively more while giving orders (22,5 \% vs. 13,8 \%). The most common depiction of women was that of a sexual object. Jančová (2006) in her analysis of Czech TV commercials came to similar conclusions. She adds an additional gender stereotype to those mentioned above: the stereotype of female laughter - women in commercials are relatively more depicted while laughing and their behavior is more prosocial. Mass media together with family and peer role models can have an effect on formation of stereotypical attitudes in population.

Stereotypes about women-managers on the basis of current researches (Moore, 2004; Fernandes, 2006) can be divided into several basic categories.

\section{Potential to lead, managerial and professional competencies:}

This category is related to capability of male and female managers to lead their subordinates, motivate them and capability to adopt and use various leadership styles. Fernandes (2006) states attributes that all successful managers should have: achievement orientation, ability to choose the right employees, awareness of business matters, good planning skills and skills related to organization of corporate processes, quick and first-rate decision making, creativity, objectivity and versatility.

2. Attributes of personality:

The second category, which are commonly objects of stereotyping are attributes of personality. Moore (2004) states the following personal attributes that a good manager should have: heartiness, emotional stability and good control of emotions, high resistance to stress, flexibility, activity, sociability and the need for social acceptance, assertiveness, credibility and interest in social interactions. 


\section{Family vs. career:}

This category is related to stereotypes related to loyalty to employer and family care. Stereotyping in this field affects only women, men are not affected because care of the household is connected only with women. The most common reason for stereotyping and the subsequent discrimination (recruitment, remuneration, promotion) is in this case the concern of the employer that a woman will leave the organization as consequence of marriage or motherhood (Stockdale, 2004).

\section{General skills:}

Among general skills are intelligence, quality and distribution of attention and memory qualities (Fernandes, 2006).

In the previous section we summarized attributes which are generally considered to be important for managing. These attributes are objects of stereotyping and they are based on various perceived rate and quality of the attributes according to whether a certain person-manager is male or female (Fernandes, 2006). The most common gender stereotypes are summarized in table 1.

Table 1: Gender stereotypes in management.

\begin{tabular}{|l|l|l|}
\hline Area & Men & Women \\
\hline Orientation & Achievement & Relationships \\
\hline Emotion & $\begin{array}{l}\text { Stable, high control, low } \\
\text { empathy }\end{array}$ & $\begin{array}{l}\text { Unstable, low control, high } \\
\text { empathy, reserved, cold }\end{array}$ \\
\hline Decision making & Fast & Indecision, postponing decisions \\
\hline Competency & Competent & Incompetent \\
\hline Interpersonal relations & Assertiveness & Need for social acceptance \\
\hline Social roles & Breadwinner & Mother, housewife \\
\hline Organisational skills & High & Low, disorganized, chaotic \\
\hline Flexibility of behaviour & Flexible, creative & Rigid \\
\hline Causal attributions & $\begin{array}{l}\text { Achievement is stable, } \\
\text { caused by dispositions }\end{array}$ & $\begin{array}{l}\text { Achievement is unstable, caused } \\
\text { by situation }\end{array}$ \\
\hline
\end{tabular}

As is apparent, the sum of stereotypes ascribed to men- and women-managers differs substantially. Not surprisingly there is also a difference between the perception of managers by men and women (Fernandes, 2006). In the whole research sample (36 Portuguese students, 22 women, 14 men) the most common characteristics of woman-manager were: "ability to motivate others" and "disorganized", when only responses of female participants were taken into consideration, the most common responses were: "active", "decisive", "competent", "pragmatic" and "organized". The results suggest that perception of men-managers is more consistent across both sexes than of women-managers. 


\section{METHODS}

\subsection{RESEARCH SAMPLE}

The research sample consisted of 111 respondents (70 women, 41 men). Relative numbers of respondents according to sex and field of study are shown in table 2. Five respondents stated more than one field of study and they are not mentioned in the table.

Table 2: Sex and field of study. ( $\mathrm{N}=106)$

\begin{tabular}{|l|l|l|l|}
\hline Sex & Field of study & N & $\%$ \\
\hline \multirow{3}{*}{ Men } & Psychology & 11 & $10,4 \%$ \\
\cline { 2 - 4 } & Economics & 29 & $27,3 \%$ \\
\hline \multirow{2}{*}{ Women } & Psychology & 44 & $41,3 \%$ \\
\cline { 2 - 4 } & Economics & 22 & $20,7 \%$ \\
\hline
\end{tabular}

The youngest respondent was 19 years old, the oldest 28 years. Average age of respondents is 23.1 years. Two thirds of respondents studied for their masters degree.

\subsection{RESEARCH METHOD AND RESEARCH QUESTIONS}

The research was conducted by questionnaires. The questionnaire consisted of 21 statements related to managerial skills and competencies, personal skills of good managers, some of the statements are related to combination of work and family life of women. The rate of agreement with each statement is evaluated on the 7-point Likert scale.

The scale was translated from original English version of WAMS (Women as Managers Scale) by Peters, Terborg and Taynor (1974). High total score means positive attitudes toward women-managers, low score means negative attitude - high rate of stereotypical thinking about women as managers. Total scale of gender stereotypes consists of 3 specific factors: overall acceptance of women as managers, barriers (preventing employment of women full-time) and personal characteristics ascribed to managers (Beere, 1990)

Example of item:

1. It is less desirable for a woman than a man to have a job that requires responsibility.

\section{Research questions:}

RQ1: Is the Czech adaptation of WAMS reliable?

RQ 2: What is the factor structure of WAMS adaptation among czech population?

RQ 3: Are the subscales of WAMS adaptation internally consistent?

RQ 4: Are there differences between men and women in the extent of gender stereotyping?

RQ 5: Which stereotypes have the highest level of identification? 


\section{RESULTS}

\subsection{RELIABILITY}

The internal consistency of the questionnaire analysis was conducted. 109 valid respondents were included. The Cronbach's a is 0,846 , the scale of gender stereotypes is internally consistent. Exclusion of no item inflicts an increase in internal reliability.

\subsection{FACTOR ANALYSIS}

The questionnaire was created by translation of the original WAMS questionnaire, according to Beere (1990) 21 items represents 3 factors:

1. Overall acceptance of women as managers (10 items, item 1-10)

2. Barriers of full-time employment (5 items, item 11-16)

3. Personal characteristics of managers (6 items, item 17-21)

Explorational factor analysis was conducted.

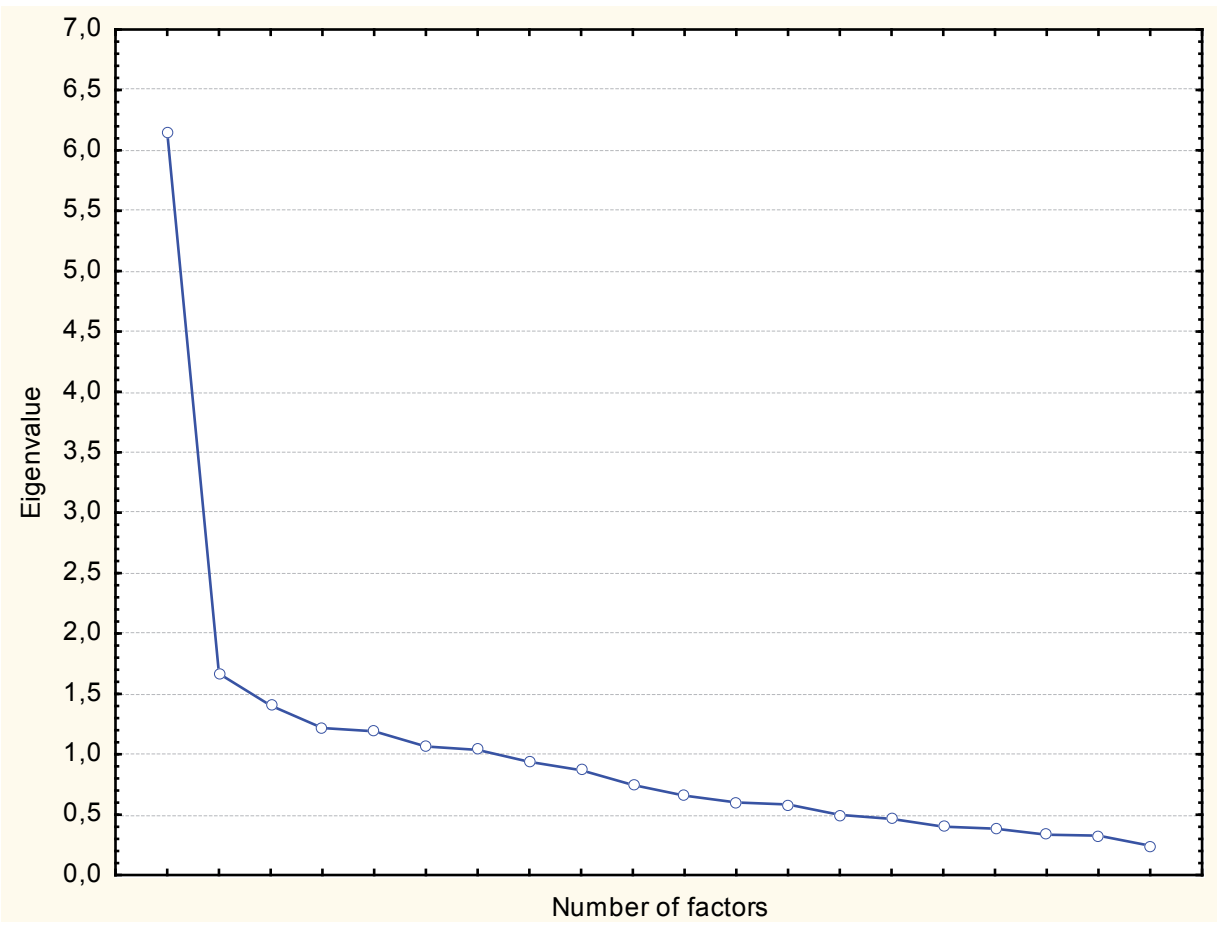

Graph 1: Eigenvalue of gender stereotypes questionnaire

As it is apparent from the graph of eigenvalues, we could, according to Kaiser-Guttman rule extract up to 7 factors. With respect to the construction of the original WAMS we have chosen 3-factor solution (normalized Varimax). Factors were extracted by the method of principal components. Factor loadings of 3-factor solution are shown in table 3. 
As is apparent from table 3, our factor structure is not consistent with the factor structure of the original questionnaire. Scale of overall acceptance is divided between factors 1 and 3. Item number 3 saturates factor 2 . More promising results were achieved by scale barriers, in which 3 out of 5 items saturate a highly common factor. Items from the scale personal characteristics saturate predominantly factor 2 . Altogether, results of factor analysis of gender stereotypes are not very satisfactory, factors are not identical with original factors in WAMS.

\begin{tabular}{|c|c|c|c|}
\hline \multirow[b]{2}{*}{ Variable } & \multicolumn{3}{|c|}{ Factor loadings (Varimax normaliz. ) } \\
\hline & $\begin{array}{c}\text { Factor } \\
1 \\
\end{array}$ & $\begin{array}{c}\text { Factor } \\
2 \\
\end{array}$ & $\begin{array}{c}\text { Factor } \\
3 \\
\end{array}$ \\
\hline GS1 & 0,613140 & 0,186037 & 0,010104 \\
\hline GS2 & 0,609511 & $-0,112645$ & 0,322109 \\
\hline GS3 & 0,052508 & 0,707803 & 0,021836 \\
\hline GS4 & 0,571522 & 0,106391 & 0,380535 \\
\hline GS5 & 0,381277 & 0,008335 & 0,724904 \\
\hline GS6 & 0,440105 & 0,270059 & 0,301030 \\
\hline GS7 & 0,167439 & 0,051189 & 0,364027 \\
\hline GS8 & 0,456896 & 0,230058 & 0,546227 \\
\hline GS9 & 0,172774 & 0,121963 & 0,734927 \\
\hline GS10 & $-0,007105$ & 0,166690 & 0,755460 \\
\hline GS11 & 0,680010 & 0,048405 & 0,165122 \\
\hline GS12 & 0,600729 & 0,002785 & 0,175283 \\
\hline GS13 & 0,338623 & 0,416307 & 0,326022 \\
\hline GS14 & 0,568502 & 0,363395 & 0,059962 \\
\hline GS15 & 0,317877 & 0,394884 & 0,251935 \\
\hline GS16 & 0,037906 & 0,440941 & 0,512920 \\
\hline GS17 & $-0,010228$ & 0,613246 & 0,066950 \\
\hline GS18 & 0,331899 & 0,190568 & 0,313732 \\
\hline GS19 & 0,025888 & 0,355370 & 0,170497 \\
\hline GS20 & 0,262946 & 0,678934 & 0,136925 \\
\hline GS21 & 0,527174 & 0,525408 & $-0,034811$ \\
\hline Var. expl. & 3,504211 & 2,664572 & 3,053333 \\
\hline Var. expl \% & 0,166867 & 0,126884 & 0,145397 \\
\hline
\end{tabular}

Table 3: Factor analysis of gender stereotypes questionnaire

\subsection{INTERNAL CONSISTENCY OF THE SUBSCALES}

On the basis of the results of the factor analysis of gender stereotypes questionnaire analysis of internal consistency of the subscales was conducted.

1. Overall Acceptance: Cronbach's a is equal to 0.71. Exclusion of item 3 leads to significant increase of internal validity - Cronbach's a rises to 0.76. Item 3 was excluded from further analysis. 
Item 3: Challenging work is more important for men than it is for women.

2. Barriers: Cronbach's a of the subscale is 0.699 which is at the borderline where the scale can be considered internally reliable.

3. Personal characteristics: Cronbach's a of the subscale is equal to 0.637. When item 19 is excluded, Cronbach's a rises to 0.666. Item 19 was excluded from further analysis.

Item 19: Women possess the self-confidence required of a good leader.

\subsection{GENDER STEREOTYPES OF MEN AND WOMEN}

Cross-gender differences in the rate of admitted gender stereotypes were tested by $\mathrm{t}$ -test (independent samples) at level of significance $\alpha=0.05$. Results are shown in table 4 .

Table 4: Gender stereotypes according to gender of respondents.

\begin{tabular}{|c|c|c|c|c|c|c|c|c|}
\hline & $\begin{array}{l}\text { Mean } \\
\text { (Men) }\end{array}$ & $\begin{array}{l}\text { Mean } \\
\text { (Women) }\end{array}$ & $\mathrm{t}$ & $\mathrm{df}$ & $\mathrm{p}$ & $\begin{array}{l}\text { SD } \\
\text { (Men) }\end{array}$ & $\begin{array}{l}\text { SD } \\
\text { (Women) }\end{array}$ & $\begin{array}{l}\mathrm{p} \\
\text { (Scatter) }\end{array}$ \\
\hline $\begin{array}{l}\text { Overall } \\
\text { acceptance }\end{array}$ & 6,05278 & 6,50476 & $-4,34341$ & 108 & 0,000032 & 0,600 & 0,477 & 0,096 \\
\hline Barriers & 4,57436 & 5,61143 & $-5,14309$ & 107 & 0,000001 & 1,155 & 0,919 & 0,098 \\
\hline $\begin{array}{l}\text { Personal } \\
\text { character. }\end{array}$ & 5,03077 & 5,69714 & $-3,39015$ & 107 & 0,000979 & 1,105 & 0,910 & 0,163 \\
\hline All scales & 5,21120 & 5,93777 & $-5,38088$ & 107 & 0,000000 & 0,755 & 0,627 & 0,181 \\
\hline
\end{tabular}

Men. compared to women, admit to a significantly higher rate of stereotyping of women as managers. This applies for all subscales of the questionnaire. Subscale Barriers (working in full-time job) is by both men and women perceived as relatively a big issue that prevents women being good managers. This subscale consists of items related to care of household, pregnancy, child-care and menstruation.

\section{DISCUSSION}

The most important limitation of the study stems primarily from the nature of the employed research method. The questionnaire was in its original English version created from items which were saturating 3 factors: overall acceptance of women at managerial level (10 items), barriers preventing women work in full-time jobs (5 items) and personal characteristics commonly ascribed to managers (6 items). Analysis of internal reliability of subscales of the questionnaire discovered two items that were not internally consistent with other items within the subscale. These items were excluded from further analysis in an attempt to improve the reliability of the test. Some respondents expressed objections to the formulation of several items (items 11, 13, 14) after administration of the test, they considered the items to be defective. These 5 items should be rephrased and their reliability should be tested on additional research samples.

Moore (2004) warns about other possible problems in this type of research. Stereotypes depend on culture, and they change in the course of time, some of them are present in the perception of both sexes, others only in the perception of one 
sex. There is a high probability that attitudes and stereotypes that are present in the Anglo-Saxon population, where the questionnaire was created, will not be applicable to the same extent in a Czech population, or their importance and strength will differ. Also, some of negative attitudes and stereotypes present in Czech culture might not be covered in WAMS.

Another source of problems might be the selection of the research sample. The respondents were students with limited work-related experience. As Vlach (2008) notes, women's perception of their own ability and capability to occupy high posts within an organization is influenced by development of their careers. For this reason it would be suitable to administer the questionnaire among people who have already built up their careers.

\section{CONCLUSION}

The primary goal of the study was to create and pilot a measurement instrument for diagnosis of the stereotyping rate of women-managers. On the basis of statistical analysis inconsistencies of factors have been identified - types of stereotypes about women as managers - between original English and Czech version of the questionnaire. Problematic items have been identified, that need to be reformulated and tested on different a research sample. We have found that women are subject to these stereotypes relatively less than men.

\section{REFERENCES}

Beere, C. A. (1990). Gender roles: A Handbook of Tests and Measures. Westport: Greenwood press.

Coltrane, S., \& Adams, M. (1997). Work-Family Imagery and Gender Stereotypes: Television and the Reproduction of Diference. Journal of vocational behaviour, 50, 323-347.

Desvaux, G., Devillard, S., \& Sancier-Sultan, S. (2010). Women at the Top of Corporations: Making it Happen. Women matter 2010. Retrieved from http://www.mckinsey.com/locations/swiss/news_publications/pdf/women_matter_2010_4.pdf

Fernandes, E., \& Cabral-Cardoso, C. (2006). The Social Stereotypes of the Portuguese Female and Male Managers. Women in Management review, 21 (2), 99-112.

Jančová, V. (2006). Analýza televizních reklam z hlediska genderových stereotypů [The Analysis of TV Commercials from Gender Stereotypes Position] (Unpublished master thesis). Masarykova univerzita v Brně, Brno.

Litzky, B. E. (2002). Senior Management Aspirations of Managers and Professionals: A Career Decision-Making Perspective [Unpublished doctoral dissertation]. Drexel University, Philadelphia.

Moore, S., Grunberg, L., \& Greenberg, E. (2004). Development and Validation of the Stereotype Beliefs about Women Managers Scale (Online working paper). USA: University of Colorado at Boulder, Institute of Behavioral Science. Retrieved from http:/ / www.colorado.edu/ibs/pubs/pec/pec2004-0008.pdf

Stockdale, M. S., \& Crosby, F. J. (Eds.) (2004). The psychology and management of workplace diversity. Oxford: Blackwell Publishing Ltd.

Vlach, J. (2005). Šetrení výdělkové nerovnosti žen a mužů v managementu [The Analysis of Salary Inequalities between Men and Women in Management]. Praha: VÚPSV.

Vlach, J., Šnajdrová, Z., Kozelský, T., \& Musil, J. (2008). Gender v managementu [Gender in Management]. Praha: VÚPSV. 